\title{
Putting people in the proper position on policy process in rural area: A deliberation and empowerment process in village level of Indonesia
}

Sukarso; Swastha Dharma; Niken Paramarti Dasuki

\author{
Faculty of Social and Political \\ Sciences University of Jenderal \\ Soedirman \\ (sukarso_upb@yahoo.co.id) (swasthadharma@gmail.com) (nikenpd@yahoo.co.id)
}

\begin{abstract}
In public policy discourse, especially the classic one, the position of society as a policy target group is often, therefore, an object of policy even in some contemporary references. The position as an object thus tends to be relatively weak compared to other positions. A top-down policy process tends to put people in a weak bargaining position. On the other hand, empowerment policies often define target groups as groups that seem to be independent and sterile from other groups. From this assumption, this study tries to formulate an empowerment model that can reposition the "target group" of the policy from objects to subjects, including redefining "target groups" into compliancers, say it is, it refers to a multi group who has to comply to the policy with deferent ways. The research method uses a case study approach with data collection techniques are in-depth interviews and focus group discussions. The results of the study get an empowerment policy model that is more deliberative and comprehensive than a partial one. This model is different from the existing models so far, both from the formulator, output, delivery system, and of course the "target group" of the policy.
\end{abstract}

Keywords: deliberative; empowerment; policy process; reposition; target group

\section{Introduction}

The old position of people in the policy-making process is remaining to the recently anyway. They have been pressed to the edge of the power so they just merely an object than a subject of the policy process. From the models of public policy making so far, the position of ordinary citizens or citizens, implicitly or explicitly, turns out to be more an object, not a subject. Explicitly on the elite model, the authority of policy-making only exists in the elite group while the people become the target of the policy, as well as implicitly in the institutional and rational model. The policy process, especially in the policy-making one, has been elitist.

Issues of democratization and people participation have risen broadly. In the past two to three decades, the issue of more community involvement in the decisionmaking process or policy making has been stronger. As a result, more and more people are involved, directly or indirectly, in the policy-making process. The use of concepts such as public-hearing and transparency shows this direction. Decentralization era in Indonesia also strengthened especially in the last two decades. In Indonesia, the era of decentralization began in 1999 with the issuance of Law No. 22/1999 on regional 
governance which was later corrected several times until now. In this era, the involvement of the community in the process (making) of policy was increasing. For example, all APBD products must go through a public hearing and must be published in the mass media. Finally, in 2014 Law No. 6/2014 was issued. about Villages. This law places the village as one of the spearheads of the government that is stronger in providing services to the community.

Being crucial position of the villages in Indonesia governmental, they should be compliance to the national government but they has to be accomodative to their people too.The position of the village in Indonesian governance is getting stronger, especially in budget allocations. The village government is given a budget allocation from the APBN directly in a relatively very large amount; with the aim is the welfare of the village community concerned. But, there is no deliberative and empowerment research of the policy process in the village level of Indonesia. So far the study of the involvement of the village community has tended to the policy process, especially participation in the policy process and not yet in the process of repositioning the village community in the policy process.

The research aim is to modeling policy process which is deliberating as well as empowering village people straightly and massively. In other words, the purpose of this study is to model a policy process that allows the community to become a policy subject, not an object of policy.

\section{Methods}

Research locations are two villages, Kotayasa and Banjarsari Kulon, in District of Sumbang, Banyumas Regency. The Kotayasa is representing a relatively big village while Banjarsari Kulon is representing the small one. The research focus is people perception and knowledge of budgeting formulation process in the village level.

Data sources of the research are informants which consist of the village government apparatus as well as the villages people, through routine neighborhood meeting while data collecting technique used both in-depth interview and focus group discussion (fgd). Data analysis technique is interactive from data collecting, condensation, display, and conclusion. 


\section{Results and Discussion}

\subsection{Brief description of the research location}

Tabel 1. Brief Description of the Research Locations

\begin{tabular}{|c|l|c|c|}
\hline \multirow{2}{*}{ No } & \multirow{2}{*}{ Description } & \multicolumn{2}{|c|}{ Research Locations } \\
\cline { 3 - 4 } & & Kotayasa & Banjarsari Kulon \\
\hline 1. & Area size & $505,99 \mathrm{Ha}$ & $212,279 \mathrm{Ha}$ \\
\hline 2. & Population & 9.157 persons & 3.516 persons \\
\hline & a. Male & 4.651 persons & 1.819 persons \\
\hline & b. Female & 4.506 persons & 1.697 persons \\
\hline
\end{tabular}

Source: obtained from primary data

\section{Pre-model of Community Participation in APBDes Formulation}

From the results of the condensation and compilation of the data in advance, it appears that one of the most prominent in the process of formulating (and implementing) the APBDes is the low level of community participation, among others, marked by nonexistent funds (zero rupiah) in the two villages of the research location. Likewise in the process of formulating activities and budgeting, community participation is very minimal, even almost none except for the real needs of physical development, such as village infrastructure. Beyond that, it seems that the village people as the subject of budgeting is still not visible. Therefore, this first year results are packaged in papers and presented at international conferences at the PublicAdministration Institute on August $21^{\text {st }}$ and $22^{\text {nd }}$, 2017 in Jakarta. The title of the paper presented at the conference was Community Participation on In Local Government Budgeting Village of Indonesia: A Case Study in Banyumas Regency, Central Java.

From the results of the discussion at the conference, the pre-model of the Formulation of Village Budgeting can be formulated with an emphasis on Community Participation, or deliberative models. This model includes empowerment and community participation with an action research approach through intervention in the form of socializing aspects relevant to the formulation of the APBDes, with the following figure1.

\section{Compilation and Condensation of Results of Interview and FGD}

From the results of interviews and FGDs, there were important aspects of the potential for optimal community involvement in the APBDes formulation process, namely (1) legal aspects, or community understanding of the various rules in the APBDes formulation 
process; (2) administrative aspects, or people's understanding of administrative systems and procedures in the formulation of the Budgeting; and (3) socio-psychological aspects, or public awareness and understanding of the rights and obligations as citizens of the community dealing with the rights and obligations of the government towards their community. Each of these aspects was then translated into the main questions as instruments of the pre-test and post-test among the brief intervention socialization materials relevant to each of these aspects. The following questions are elaborated on each aspect and concise material of the intervention relating to that understanding.

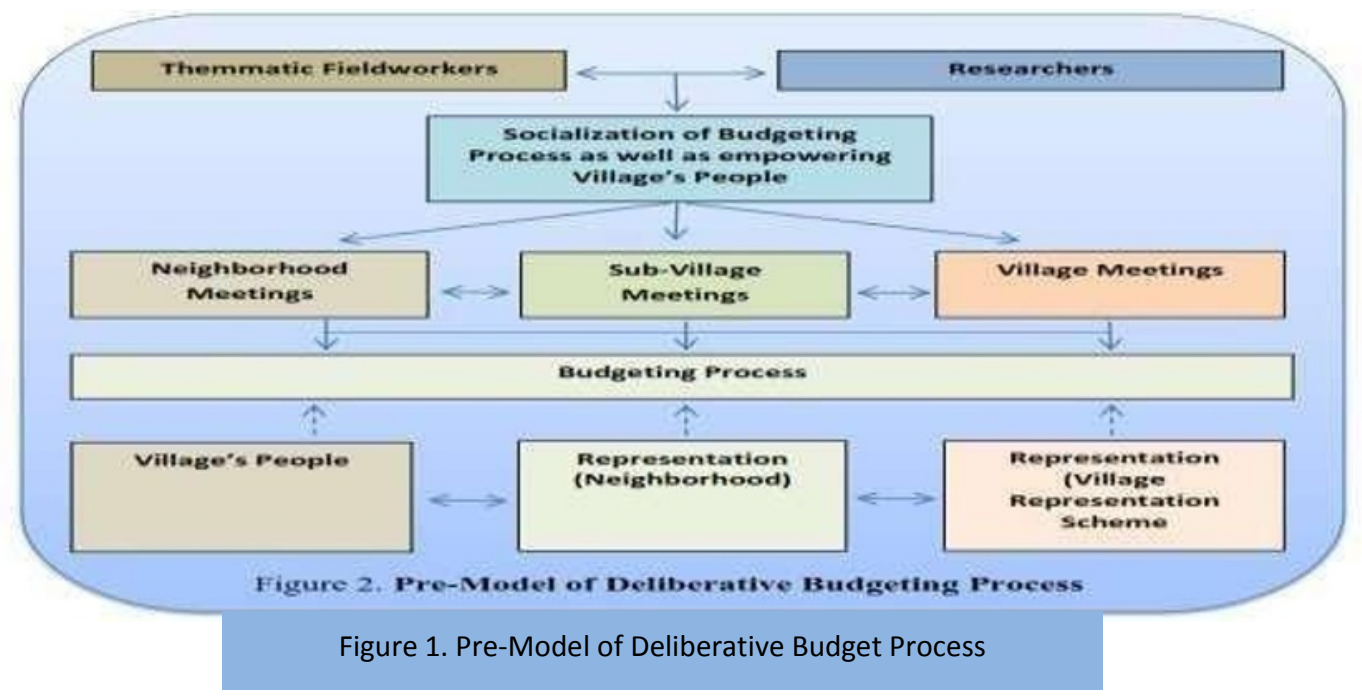

Results of the Pre-test and Post-test

The number of respondents selected by random cluster was 67 respondents, with details of 24 respondents were residents of Banjarsari Kulon Village and 43 respondents were residents of Kotayasa Village. The instruments are in the form of a scale with three answer choices 1 (low), 2 (medium), and 3 (high). The results of the pre-test and post-test can be examined in the following table 2 .

From the table, it appears that the intervention in the form of socialization and increasing community understanding through FGD in these three aspects turned out to be very effective. Likewise, the potential for community involvement (item $3 \mathrm{~b} ; 3 \mathrm{~d} ; 3 \mathrm{f} ; 3 \mathrm{~h}$; and $3 \mathrm{j}$.) Turns out to be very high, in other words, through increasing community understanding of the APBDes formulation process can increase community involvement in the APBDes formulation process. Increasing community involvement in the process of formulating the APBDes is the first step to repositioning the village community from the APBDes object to be the subject of the APBDes. 
Table 2. The Change of People's Perception and Knowledge Regarding Village Budgeting Process After "Intervention"

\begin{tabular}{|c|c|c|c|c|}
\hline \multirow{2}{*}{ No. } & \multirow{2}{*}{ Description } & Pre-test & Post-test & Change \\
\hline & & $f(x)$ & $f(x)$ & $\%$ \\
\hline 1. & \multicolumn{4}{|l|}{ Legal Aspects } \\
\hline a. & $\begin{array}{l}\text { Do you know the rules about managing the } \\
\text { Village Budgeting? }\end{array}$ & $\begin{array}{c}87 \\
(1,29)\end{array}$ & $\begin{array}{c}138 \\
(2,05)\end{array}$ & Naik $58 \%$ \\
\hline b. & If you know, mention what are the rules? & $\begin{array}{c}77 \\
(1,14)\end{array}$ & $\begin{array}{c}146 \\
(2,77)\end{array}$ & $89,6 \%$ \\
\hline c. & $\begin{array}{l}\text { Do you know the sanctions for violations or } \\
\text { misuse in the management of APBDes? }\end{array}$ & $\begin{array}{c}92 \\
(1,37)\end{array}$ & $\begin{array}{c}163 \\
(2,43)\end{array}$ & $77,1 \%$ \\
\hline d. & If you know, mention these sanctions? & $\begin{array}{c}86 \\
(1,28)\end{array}$ & $\begin{array}{c}156 \\
(2,32)\end{array}$ & $81,3 \%$ \\
\hline e. & $\begin{array}{l}\text { Do you know the difference in sanctions for } \\
\text { criminal, civil and administrative? }\end{array}$ & $\begin{array}{c}94 \\
(1,4)\end{array}$ & $\begin{array}{c}158 \\
(2,35)\end{array}$ & $68 \%$ \\
\hline 2. & \multicolumn{4}{|l|}{ Administrative Aspects } \\
\hline a. & $\begin{array}{l}\text { According to you, who is authorized and } \\
\text { responsible for managing the Regional } \\
\text { Budget? }\end{array}$ & $\begin{array}{c}88 \\
(1,31)\end{array}$ & $\begin{array}{c}186 \\
(2,77)\end{array}$ & $111,3 \%$ \\
\hline b. & $\begin{array}{l}\text { Do you know about the APBDes } \\
\text { formulation schedule? }\end{array}$ & $\begin{array}{c}80 \\
(1,19)\end{array}$ & $\begin{array}{c}146 \\
(2,17)\end{array}$ & $82,5 \%$ \\
\hline c. & $\begin{array}{l}\text { Do you know about the types of funds } \\
\text { available at the APBDes? }\end{array}$ & $\begin{array}{c}82 \\
(1,22)\end{array}$ & $\begin{array}{c}180 \\
(2,68)\end{array}$ & $119,5 \%$ \\
\hline $\mathrm{d}$. & $\begin{array}{l}\text { Do you know the allocation or allocation of } \\
\text { these types of funds? }\end{array}$ & $\begin{array}{c}82 \\
(1,22)\end{array}$ & $\begin{array}{c}177 \\
(2,64)\end{array}$ & $115,8 \%$ \\
\hline e. & $\begin{array}{l}\text { Do you know the amount of each type of } \\
\text { fund that is in the APBDes? }\end{array}$ & $\begin{array}{c}79 \\
(1,79)\end{array}$ & $\begin{array}{c}156 \\
(2,32)\end{array}$ & $97,4 \%$ \\
\hline f. & $\begin{array}{l}\text { Do you know the final balance becomes the } \\
\text { starting balance for the following year? }\end{array}$ & $\begin{array}{c}80 \\
(1,19)\end{array}$ & $\begin{array}{l}140 \\
(2,08)\end{array}$ & $75 \%$ \\
\hline 3. & \multicolumn{4}{|l|}{ Socio-psychological aspects } \\
\hline a. & $\begin{array}{l}\text { Do you understand the process of } \\
\text { formulating the APBDes? }\end{array}$ & $\begin{array}{c}84 \\
(1,25)\end{array}$ & $\begin{array}{c}152 \\
(2,26)\end{array}$ & $80,9 \%$ \\
\hline b. & $\begin{array}{l}\text { Do you want to participate in the APBDes } \\
\text { formulation process next year? }\end{array}$ & $\begin{array}{c}142 \\
(2,11)\end{array}$ & $\begin{array}{c}189 \\
(2,82)\end{array}$ & $33 \%$ \\
\hline c. & $\begin{array}{l}\text { Do you understand the implementation of } \\
\text { the Regional Budget? }\end{array}$ & $\begin{array}{c}84 \\
(1,25)\end{array}$ & $\begin{array}{c}109 \\
(1,62)\end{array}$ & $29,7 \%$ \\
\hline d. & $\begin{array}{l}\text { Do you want to participate in next year's } \\
\text { APBDes? }\end{array}$ & $\begin{array}{c}130 \\
(1,94)\end{array}$ & $\begin{array}{c}188 \\
(2,80)\end{array}$ & $44,6 \%$ \\
\hline e. & $\begin{array}{l}\text { Do you know the monitoring process in } \\
\text { implementing the Regional Budget? }\end{array}$ & $\begin{array}{c}77 \\
(1,14)\end{array}$ & $\begin{array}{c}146 \\
(2,17)\end{array}$ & $89,6 \%$ \\
\hline f. & $\begin{array}{l}\text { Do you want to participate in the process of } \\
\text { monitoring the implementation of the } \\
\text { Regional Budget next year? }\end{array}$ & $\begin{array}{c}143 \\
(2,13)\end{array}$ & $\begin{array}{c}192 \\
(2,86)\end{array}$ & $34,2 \%$ \\
\hline g. & $\begin{array}{l}\text { Do you know the supervision in the } \\
\text { implementation of the Regional Budget? }\end{array}$ & $\begin{array}{c}77 \\
(1,14)\end{array}$ & $\begin{array}{c}135 \\
(2,01)\end{array}$ & $75,3 \%$ \\
\hline h. & $\begin{array}{l}\text { Do you want to participate in monitoring the } \\
\text { implementation of the Regional Budget next } \\
\text { year? }\end{array}$ & $\begin{array}{c}140 \\
(2,08)\end{array}$ & $\begin{array}{c}193 \\
(2,88)\end{array}$ & $37,8 \%$ \\
\hline i. & $\begin{array}{l}\text { Do you know the results of the APBDes } \\
\text { implementation? }\end{array}$ & $\begin{array}{c}93 \\
(1,38)\end{array}$ & $\begin{array}{c}156 \\
(2,32)\end{array}$ & $67,7 \%$ \\
\hline $\mathrm{j}$. & $\begin{array}{l}\text { Do you want to participate in measuring the } \\
\text { results of the next year's APBDes? }\end{array}$ & $\begin{array}{c}81 \\
(1,20)\end{array}$ & $\begin{array}{c}136 \\
(2,02)\end{array}$ & $67,9 \%$ \\
\hline
\end{tabular}

Note: $n=67 ;$ Scale $=1$ to 3

Source: obtained from primary data 


\section{Discusion}

Stakeholders in the formulation of APBDes.

The process of formulating the APBDes is actually directly or indirectly involving parties (1) Village Heads, (2) Secretaries and Village Devices, (3) Village Consultative Bodies (BPD), (4) sub-districts represented by Village Facilitators, and (5 ) Village communities in general. But it turns out that formally and real in the field, the parties involved are mainly Village Heads, Secretaries and Village Devices, and the BPD. The role of Village Facilitators turns out to be optional and the role of the community is directly very small or almost non-existent. The process of formulating the APBDes relatively only involves the Village Government and the BPD as well as (approval) from the District Government (via the sub-district).

\subsubsection{Stakeholders Interaction.}

The intense communication and discussion in the process of formulating the APBDes is mainly between the Village Government and the BPD and the District Government (through the District). The community does not directly communicate in the formulation process because it has been represented by the BPD. The following illustration explains the relationships between stakeholders in the process of formulating the APBDes.

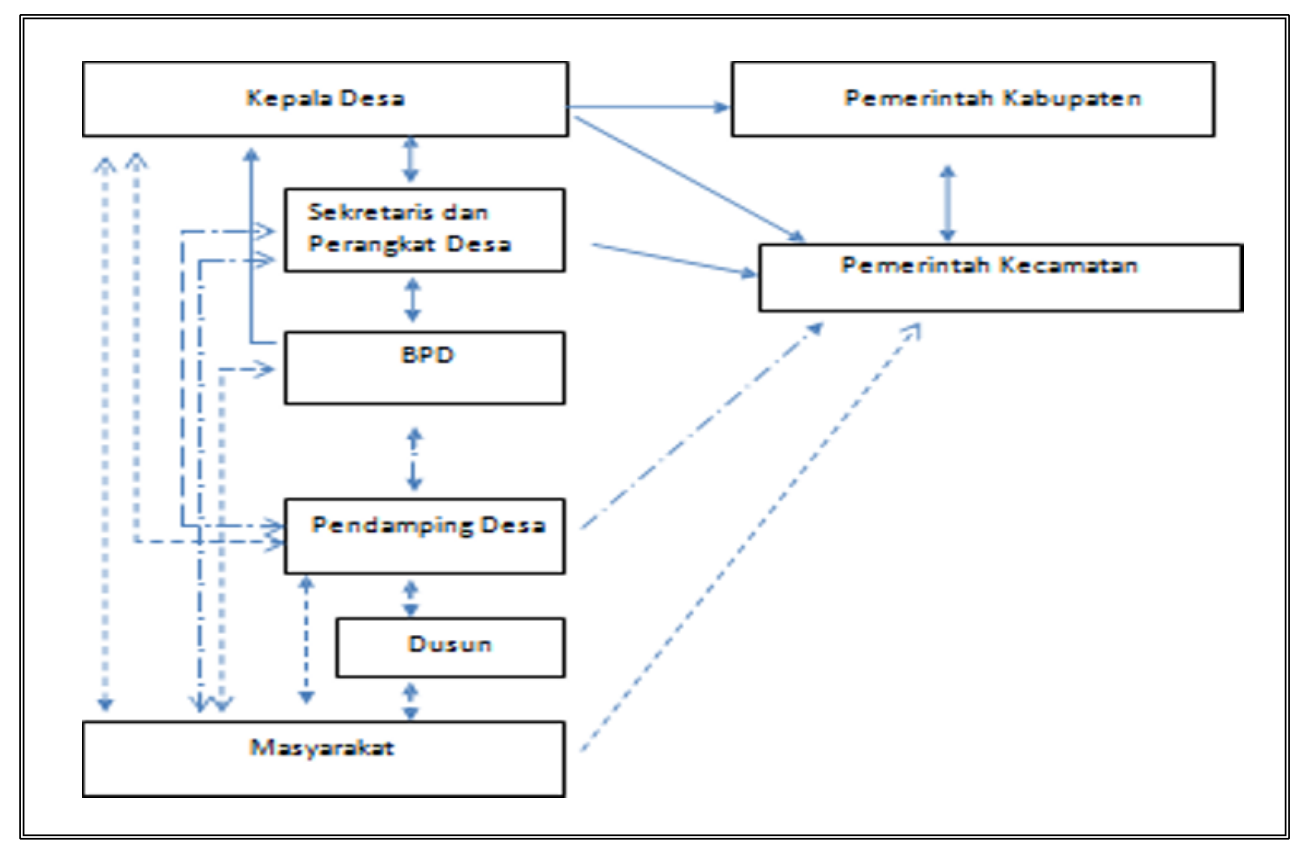

Source: obtained from primary data

Figure 2. The Stakeholders Interactions 


\section{Direct participation of village people: the subject of formulation.}

From the results of the field study it appears that the role of the community directly in the process of formulating the APBDes is still very minimal and almost nonexistent, both formal and real access. The community tends to not know what and how the APBDes formulation process is, but actually the community needs and wants to know what and how it is. Therefore, there is a big possibility to increase community participation in the process of formulating the APBDes by giving opportunities to the community to be involved. The process of involving the community is more than just socialization, but there is a discourse on community empowerment in general on what and how to formulate the APBDes. The design in the pre-model is a scheme of how to increase community participation in the process of formulating the APBDes. The process of invasion and intervention, the final result that will be achieved is to place the village community as the subject of the formulation of the APBDes, not as an object as it has been.

Prospects of the People Position in the the Village Budgeting Process. From the results of the pre-test and post-test, it appears that the intervention in the form of socialization and increasing community understanding in the APBDes process can increase community participation in the APBDes process. Therefore it can be strongly suspected that the position of the community can shift from the APBDes object to the subject of the Regional Budget with an increase in people's understanding. Efforts to improve people's understanding can be done by creating a community empowerment module covering legal, administrative and socio-psychological aspects. Increasing public understanding in legal aspects includes legal awareness and legal knowledge in the form of various regulations relevant to the formulation of the Regional Budget. Increasing public understanding in administrative aspects relates to community understanding in the APBDes formulation system and procedures. The increase in public awareness in the socio-psychological aspects is related to awareness of their rights and obligations in dealing with the rights and obligations of the government in the formulation of the APBDes.

\section{Conclusion}

From the results of the discussion, it appears that the need of the village community to be able to reposition them from the object of the formulation of the APBDes which is the 
subject of the formulation of the APBDes is very possible. From the results of a simple intervention in the second year, it was proven that increasing community understanding of the formulation of the APBDes could increase their participation in the formulation process and even the implementation of the Regional Budget. Therefore, in the third year, the final program in this study will be formulated in a more detailed and rigid manner and a retesting of the module to improve community understanding in the APBDes in the form of the Community Empowerment Module in the APBDes Process. This module formulation effort will be carried out in the third year, with an action research approach, which will include socialization and at the same time empowering the community about what and how to formulate the APBDes. These efforts, from the legal aspect, are efforts to increase legal knowledge and awareness, especially those related to the Regional Budget. In this case, the community becomes increasingly aware of what and how the rights and obligations of the community and government must be carried out in accordance with applicable regulations.

From the sociological aspect, these efforts are related to their awareness of the position that should be the subject of the formulation of the APBDes, not as an object. In this case, the community can increasingly realize what and how personal interests and the interests of society in general can walk together in balance. From the psychological aspect, these efforts are related to people's confidence and their existence in the process of formulating the APBDes. In this case, the community is increasingly able to actualize their interests in the process of budgeting their respective villages. Socialization and community empowerment in the APBDes formulation process became the central theme in the second year research activities. Thus, the third year research will contain inventions and interventions through the community empowerment module in the APBDes. To increase community involvement and continue to assist the process of involvement of the community concerned in the process of formulating their respective APBDes.

\section{Acknowledgement}

We wish to express our sincere thank to Ministery of Research, Technology and High Education of Indonesia for funding the research

We sincerely thank Mrs. Nani and Mr. Kokar, Head of Government of Kotayasa and Banjarsari

Kulon Villages for facilitating the research where have been carried out. 


\section{References}

[1] Albert-Roulhac, Catherine, 1998, The Influence of EU Membership on Methods and Processes of Budgeting in Britain and France, 1970-1995, on Governance: An International Journal of Policy and Administration, Vol. 11, No. 2, April 1998 (pp. 209-230). 1998.

[2] Dexter Whitfield, 2001, Public Services or Corporate Welfare: Rethinking the Nation State in the Global Economy, Pluto Press, London.

[3] Dinb, Hinh T., Abebe Adugna and Bernard MyersI, (2002), The Impact of Cash Budgets on Poverty Reduction in Zambia: A Case Study of the Conflict between Well-Intentioned Macroeconomic Policy and Service Delivery to the Poor, on The World Bank Africa Region Poverty Reduction and Economic Management Division, 1 October 2002

[4] Jacobs, Keith, 2001, Devolved Budget Making within Local Authority Housing Departments: Staff Perceptions of Power and Control, on Local Government Studies, Vol.27, No.2 (Summer 2001), pp.93-110.

[5] Mikesell, John, 2007, Fiscal Administration in Local Government: An Overview, on Anwar Shah (Ed.), 2007, Local Budgeting (Public Sector Governance and Accountability Series), The International Bank for Reconstruction and Development/The World Bank.

[6] Kelly, Joanne, 2000, Budgeting and Program Review in Canada 1994-2000 on Australian Journal of Public Administration Vol. 59(3):72-78, Sept-2000.

[7] Lewis, Carol W., How to Read a Local Budget and Assess Government Performance, on Anwar Shah (Ed.), 2007, Local Budgeting (Public Sector Governance And Accountability Series), The International Bank for Reconstruction and Development/The World Bank.

[8] Mullins, Danielr, 2007, Local Budget Process, on Anwar Shah (Ed.), 2007, Local Budgeting (Public Sector Governance and Accountability Series), the International Bank for Reconstruction and Development/the World Bank.

[9] Miles, Matthew B., A. Michael Huberman and Johnny Saldana, 2014, Qualitative Data Analysis: A Methods Sourcebook, 3rd edt., Sage, Los Angeles.

\section{Abbreviation:}

APBDes: Anggaran Pendapatan dan Belanja Desa (The Village's budgeting) 